\title{
The Effect of Pre-Post Bank Consolidation on the Accessibility of Finance to SMEs in Nigeria
}

\author{
Kehinde A. Obasan \\ Department of business administration, Olabisi Onabanjo University, Ago - Iwoye, Nigeria \\ Tel: 234-805-614-1961_E-mail: obasankehinde@yahoo.com \\ Kareem A. Arikewuyo (Corresponding author) \\ Department of economics and financial studies, College of management and social sciences \\ Fountain University, Osogbo, Nigeria
}

Tel: 234-803-406-1631_E-mail: abees4you@yahoo.com

Received: July 6, 2012

doi:10.5430/bmr.v1n3p108
Accepted: August 20, 2012

Online Published: September 6, 2012

\begin{abstract}
Small and Medium Enterprises (SMEs) has been acknowledged as tool for solving basic economic problem of unemployment as it plays a significant role in economic growth and development. The Nigerian banks were characterised by poor capital base to foster economic development and growth, hence the need for consolidation. This study was carried out to ascertain whether bank consolidation exercise in Nigeria had improved accessibility of finance to SMEs in Nigeria or not. This study uses empirical analysis (Ordinary Least Square). The study found out that banks' consolidation has failed to foster a vibrant and competitive SMEs sector that could enhance job creation and economic growth in Nigeria, thus the need for government intervention. This study, therefore, submits that the government should evolve a workable policy at directing banks to channel finance to SMEs so that bank can play an active developmental role to achieve economic growth and development in Nigeria.
\end{abstract}

Keywords: Bank Consolidation, Finance, SMEs and Economy

\section{Introduction}

The fulcrum of economic development worldwide revolves around banking institutions which have the statutory capacity to mobilize deposits from surplus savers and grant credit facilities to deficit spenders/or investors. The potent of banks' intermediation process lies in their ability to create money through multiple credit expansion on economic activities whose recipient beneficiaries return the proceeds back to banks in the form of deposit. Banks' ability to create money is however constrained in situations where loans granted turn out to be non- performing. This means that the loans granted do not return to banks as deposit for further credit to other investors/or consumers.

The economic development of any nation cannot be achieved without the growth of Small-medium Scale Enterprises (SMEs) sector. This sector which is the engine of growth requires much needed sustainable development of a nation especially in terms of job and wealth creation. The success of bank lending and recovery process is hinged on "realizable collaterals" that are convertible to cash in the event of default. But this has been the root cause of small and medium enterprises (SMEs) lack of access to finance from the banking system worldwide.

One of the problems that bedevilled the Nigerian economy is the poor performance of the Small and Medium Scale Enterprises of the economy. This parlous state of affairs with the SMEs is due to many problems which include weak purchasing power amongst a generality of the population that directly translates to depressed demand, a high cost operating environment arising from collapsed infrastructural decay to exchange rate. Small and medium scale enterprises, be it as it may, when properly funded and managed can realise the potential benefits for a virile SMEs (Chizea, 2002). This sub-sector contributes to the national objective of creating employment opportunities, training entrepreneurs, generating income and providing a source of livelihood for the majority of low-income households in the country. 
Many problems are encountered in establishing businesses in urban or rural communities. Hence the establishment of SMEs must be well planned so that they do not take off and die as a result of non-proper funding. Small and medium scale enterprises have some common problems in all countries and perhaps the most basic problems are lack of access to fund and credit facilities to sustain their growth and development. Many SME operators are unaware of the basic requirements needed to access finance from the banks. Credit is no doubt a critical input for industries in general.

Banking sector, in the pre-consolidation period, was characterised by small banks with low capital base averaging \$10million, hence the need for bank consolidation. The essence of consolidation was to strengthen banking sector through recapitalisation and to shore-up the capital base to $\$ 25.0$ billion which was achieved via capital markets as well as mergers and acquisitions.

The Financial Sector Strategy (FSS 2020) on the other hand, is a complementary reform blueprint designed to transform the financial sector into a growth catalyst in order to make Nigeria a "financial hub" in Africa and to achieve Nigeria's goal to become one of the top 20 economies in the world by the year 2020 .

The vision's strategy includes helping to build a vibrant SME sub-sector, known to be the nucleus of industrial development worldwide. To achieve this, the banks needed to be recapitalized to enable them play their role.

The SME development vision states that:

"By 2020, our credit to GDP ratio will be among the top three of emerging markets, with the most productive SME sub-sector and 70 per cent of the Nigerian population having access to credit".

The above stated vision for the SME hopes to make credit accessible, convenient and affordable. It also hopes to foster a vibrant and competitive micro, small and medium enterprises sector that will enhance job creation, promote economic growth, reduce poverty and create wealth. This vision cannot be achieved if the banks continue to shy away from financing SME activities and growth in the country.

However, the seminal role played by SMEs notwithstanding its development is everywhere constrained by inadequate funding and poor management. The unfavourable macro-economic environment has also been identified as one of the major constraints which most times encourage financial institutions to be risk-averse in funding small and medium scale businesses. The reluctance on the part of financial institution to fund SMEs can be explained by the insufficient capital base of banks and information asymmetry that often exists between SMEs and lending institutions.

The catalyst for the growth of the Nigerian economy lies in the banking system through efficient allocation of credit, especially to the real sector. Unfortunately, banks' post consolidation credit administration has continued to neglect the small and medium enterprises and real sector development. The huge capital acquired by the banks during the consolidation exercise has been largely channelled to non-SME, non- real sector, bad and doubtful loans. It was estimated that about 20 per cent of the banking system capital had been eroded through non-performing loans.

Against this background, this paper appraises the accessibility of SMEs to finance during pre and post consolidation eras in Nigeria. The study did use secondary data from 1992 to 2010. The rest of this paper is organised as follows section two reviews the literature, section three covers the methodology, section four contains data analysis while section five concludes the study.

\section{Literature Review}

\subsection{Introduction}

Many scholars including Jegede (1990) and Ihyembe (2000) believe that there is no universally accepted definition of Small and Medium Scale Enterprises (SMEs) as their definitions differ from one country to another, from one industry to another and it is also a function of one or a combination of two factors. They argued that the yardstick employed in determining what constitutes Small and Medium Scale Enterprises depends largely on the level of development of a given country. According to them, their definitions undergo periodic changes that reflect rising costs of equipment, wage increase, increase in the rate of exchange of local currency, etc.

Eigbe (1996) sees Small and Medium Enterprises (SMEs) is a catalyst to socio-economic development of any country. They are veritable vehicle for the achievement of national macro-economic objectives in terms of employment generation at low investment cost and the development of entrepreneurial capabilities and indigenous technology. According to this scholar, the roles of SMEs have been amply displayed in many countries such as Japan, South Korea, India and Malaysia. He argued further that they contribute substantially to the Gross Domestic Products (GDP), export earnings and employment opportunities of these countries. 
The banks' effectiveness and efficiency in performing their roles, particularly the intermediation role between the surplus and deficit unit of the economy, depends largely on largely on the level of development of the financial system. The more developed and sophisticated financial systems tend to be associated with the matured economies while under-developed financial system is characterised in developing economies. As a process, the financial system adjusts to changes in the real economy just as the economy responds to development in the financial sector. Recapitalisation of banks in Nigeria is intended among others to help mobilise domestic savings, deepening and broadening intermediation, improve allocation of resources and helping to mobilise foreign savings.

On the other hand, because SMEs do not have access to capital market so they naturally depend on banks for funding. Dependence on banks makes them even more vulnerable as shocks on the banking system would have significant effects on the supply of funds to SMEs. Thus, SMEs are subject to funding problems and these problems are exacerbated during periods of financial instability. Berger and Ulder (2001) further note that shocks to economic environment in which both banks and SMEs exists can significantly affect the willingness and capability of banks to lend SMEs. These shocks come in a variety forms such as technological innovation, regulatory regime, shifts in competitive conditions and changes in the macro-economic environment.

\subsection{Small and Medium Enterprises - An Operational Definition}

Classification of industries into small, medium or large scale is a matter of subjective judgement. To that extent, there cannot be a universally acceptable definition of Small and Medium Enterprises. Besides, what may be considered as Small-Medium Enterprises (SMEs) in a developed economy like the United States may not even qualify to be classified as such in developing economies. Conversely, a Large-Scale industrial venture in Nigeria may be what the United States Industrial authorities will label as a mere "small enterprises".

Generally, the definition is usually centres around the level of capital and assets. That is to say whether an enterprise is classified as small or large will depend on the level of capital or assets of the enterprise. The definition also changes with time based on the circumstances, changes in government policies, the level of capitalisation, size of the enterprise, size of the manpower, turnover and volume of local raw materials involved.

World Bank (1988) defines SMEs as an enterprise whose total fixed assets (excluding land) plus working capital does not exceed $\$ 10$ million in constant 1988 prices. This means that a general increase in the price level will, normally bring about a rise in the upper limit of the Small-Medium Enterprises capital outlay within this definition. Ihyembe (2000) opines that since the concept connotes different things to different people, most definitions are done for the purpose of convenience and centre around any or a combination of criteria.

In Japan, definitions are based on particular industry. In Japanese manufacturing sector, a small business is one with paid up capital of 100 million Yen and employing at least 100 staff but a small business in the retail sector is required to have paid-up capital of at least 10 million Yen and 50 employees.

CBN (1988) defines a Small and Medium Enterprise as an organisation whose investments (including land and working capital) do not exceed $\$ 5.0$ million. Small and medium scale enterprise is also seen as an investment with total capital of between $\$ 100,000$ and $\$ 2$ million excluding land but including working capital, while cottage and micro-cottage industries are seen as investment with capital not exceeding $\$ 100,000$ excluding land but including working capital (NIPC, 1999). More so, SMIES and NERFUND (2004) define Small and Medium Enterprise as an enterprise with an asset base not exceeding \$200 million excluding land and working capital with staff strength of not less than 10 and not more than 300. However, SME has been classified and tabulated into: Employment-Based; Asset and Revenue Based.

$$
\begin{aligned}
& <\text { Insert Table 1> } \\
& <\text { Insert Table 2> }
\end{aligned}
$$

It is, however, important to note that attempts to define Small and Medium Enterprises (SMEs) are generally diverse and sometimes conflicting. Definitions are based on a number of criteria, which vary from one place to another. Therefore, it is difficult to sum up the definition of Small and Medium Enterprises (SMEs) in one brief statement. According to Ihyembe (2001), the constant adaptation to the needs of the society makes it, at best a moving target for definition. Anyanwu (2001) argues that capital investment and turnover are widely employed because they are very functional and easy to measure.

\subsection{SMEs and Nigerian Economy}

Many economies - developing and developed have come to realise the value of SMEs as they are seen to be characterised by dynamism, witty innovation, efficiency and their size allows for faster decision-making process. 
SMEs have been recognised as the engine through which the growth objectives of developing nations can be achieved. They are potential sources of employment and income in many developing countries (Daniels, 1994; Daniels and Ngirira, 1992; Daniels and Fisseha, 1992). It is also argued that an increase in employment via SMEs is not always associated with increase in productivity. Nevertheless, the important role played by these enterprises cannot be over-looked. SMEs are advantageous over their large scale competitors as they are able to withstand adverse economic condition.

The promotion of SMEs has been recommended worldwide as a viable development strategy for developing nations that are plagued with socio-economic problems of unemployment, poverty, low capital formation, low growth rate, etc. The importance of SME in the Nigerian economy cannot be over-emphasized as successive governments have designed and implemented different programmes targeted at providing an enabling environment for SMEs to survive. The earliest attempt of government in Nigeria to develop SMEs dates back to 1946 when the sessional paper No. 24 of 1945 on "A Ten-Year Development Plan and Welfare Of Nigeria" was presented as amended by the selected Committee of Council and approved by the Legislative Council in 1946. The first stage of the development loan involved the establishment of a "Nigeria Local Development Board saddled with the responsibility of promoting and developing village crafts and industries as well as developing the products of Nigeria, among other things.

In pursuance of this scheme, it was intended that SMEs could be developed to attain higher level of efficiency so that they could be more remunerative to the operators. Thus, the World Bank reported that the country has not made any significant progress in its industrial development as out of 22 million pounds allocated for investment in the Ten-Year Development Plan, only 6 million pounds was actually utilised. Laudable as this intention were, this dream could not materialise because of the colonial economic arrangements and structures which prevailed in the country. Although, there was no coherent policy aimed at promoting SMEs during the pre-independence era.

In Nigeria's First Development Plan of 1962-1968, not much effort was made to develop Small and Medium Industries. The Federal Government's major policies in the area of trade and industries were focused on import substitution policy. Government in the 1960s laid emphasis on light industry and assembling plants as Industrial Development Centres (IDCs) were established and these IDCs assisted in financing Small and Medium Industries in the area of techno-managerial services but these laudable projects were halted by the civil war.

The government continued the import substitution policy as industrialisation strategy during Second National Development Plan of 1970 -1975. As economy became bloated from the oil boom, industrial projects with high capital outlay were undertaken. Private sector investment in manufacturing grew, though with less emphasis on Small and Medium scale Enterprises (SMEs) while that of Third National Development Plan of 1975 - 1980 was the development of a more diversified and integrated industrial structure based on the large domestic market and rapidly rising incomes. Industrial production failed to maintain its momentum during this period due to rising inflation, increased competition from imports and growing inefficiencies within the manufacturing sector. Also, the Fourth National Development Plan stressed the importance of Rapid economic growth especially in the non-oil sector and greater participation in ownership and management of productive enterprises.

Therefore, the economic conditions that prevailed in the country during 1970s and 1980s made people to argue that Large-scale industries have not played and cannot alone be expected to play the dynamic role in the rapid growth and development of the Nigerian economy (Jegede, 1990).

In short, the Nigerian government's intervention in SME finance comes in two main ways:

Institutional arrangement which were established by government to create enabling institutions that directly or indirectly provide finance for SMEs operations such as BOI (formerly NIDB); NBCI - now defunct; NACRDB (formerly NACB); Nigeria Export-Import Bank (NEXIM),etc. The institutions created to facilitate the flow of funds to SMEs through capacity building and provision of enabling environment includes SMEDAN, NEPC, NIPC and Relevant Government Ministries, Departments \& Agencies involved in SME finance and promotion, etc.

(ii) Government Financing Programmes are either direct or indirect. The former involves direct dispensation of cash, equipments and other forms of capital to various SME promoters such as: Small scale Industries Loan Scheme by FMF in 1971 - now defunct; Tractor Hiring Scheme by Federal and States Government; Keke NAPEP and other Small loan scheme by the National Agency for Poverty Eradication Programme (NAPEP), etc. Indirect financing, on the other hand, involves offering some form of guarantee to a third party to provide finance to SME promoters in a particular sector of the economy such as World Bank Assisted Loan Scheme - guaranteed by the Federal Government, Central 
Bank of Nigeria's Financing Schemes which include Agricultural Credit Scheme Fund (ACGSF); Trust

Fund Model (TFM); Small and Medium Enterprises Equity Investment Schemes (SMEEIS), etc.

However, all efforts made in the past to attract real sector finance from the banking system have largely been unsuccessful. Part of the problem has been blamed on the Federal Government's inability to provide the required infrastructure and conducive environment for business to thrive.

Benjamin (2009) opines that Nigeria's growth strategies could therefore be summarized as follows:

i. Stable macro-economic policies;

ii. $\quad$ Credit to real sector

iii. SME development

iv. Legal/administrative framework

v. Infrastructural development

vi. $\quad$ Peace and security

The catalyst for the growth of the Nigerian economy lies in the banking system through efficient allocation of credit, especially to the real sector. This corroborates with Nnana's (2001) findings that small and medium scale enterprises needs funds to bring together the other factors of production - land, labour and capital for production to take place. Unfortunately, Small and Medium scale Enterprises have been discriminated against by financial institutions because of high risk associated with financing them. Nnana (2003) acknowledges that SMEs are considered generally as the bedrock of the industrial development of any country.

\subsection{Nigerian Financial System AND SMEs}

Modern commercial banking in Nigeria dates back to colonial era with the establishment of two British banks between 1892 and 1933, principally to carter for the payment of salaries and other banking services to colonial administrators. These two banks were Bank of British West Africa and Barclays Bank. The name "Bank of British West Africa" was so indicative of the fact that its services were principally meant for the British people living in West Africa. It is clear, therefore, that the objects of these British banks did not include the development of the Nigerian economy or financing of real sector SMEs.

Between 1933 and 1951, many indigenous banks were established essentially to balance the biased credit policies of the expatriate banks. Unfortunately, many of them failed as soon as they were set up because of mismanagement. This phenomenon led to legislation of banking activities through the Banking Ordinance of 1952 and its amendments in 1958. At the eve of independence, it became imperative to establish a central bank that would supervise the activities of the banks and also take sovereignties over legal tender issues. Consequently, the Central Bank Act of 1958 was promulgated and the Bank commenced operations on 13t h July, 1959.

At independence in 1960, the total numbers of surviving banks were twelve with a total of 160 branches across the country. However, by 1966, the number of banks rose to fifteen with 253 branches across the nation. Of this number, six banks were indigenously owned with 82 branches across the nation. The dichotomy between the indigenous and expatriate banks became prominent.

The post-independence policy of government that took over 60 per cent of the equity capital of the expatriate banks and nationalised the major indigenous banks helped to dilute the dichotomy between the expatriate and indigenous banks as well as put the indigenous banks on a stronger financial footing. By end 1977, the number of banks rose to 19 with 492 branches across the nation.

At the eve of consolidation of banks in 2004, there were 89 banks with 3,492 branches across the nation, out of which 5 were off shore. However, the capital adequacy ratio of these banks continued to be weak and some below the minimum prescribed by BASEL II Capital Accord. Their lending practices favoured general commerce and services rather than real sector development. It therefore became necessary to restructure and reposition the banks to meet the emerging challenges.

The CBN's assessment of the 89 banks, based on their returns, classified 62 as sound/satisfactory, 14 as marginal and 11 as unsound as at end-March, 2009. Further analysis of the marginal and unsound banks showed that they accounted for only 19.2 per cent of the total assets of the banking system, 17.2 per cent of total deposit liabilities and 19.5 per cent of the industry's non-performing assets. Those banks were hamstrung by persistent liquidity problem, poor asset quality and unprofitable operations.

At the expiration of the deadline of 31st December, 2005, eighty nine (89) of the existing banks consolidated into twenty five (25) banks through mergers, acquisitions and take-overs or higher capital base. The remaining fourteen 
(14) banks could not consolidate and were liquidated by the NDIC. Two banks later merged in September, 2007, bringing down the number of banks operating in Nigeria to twenty four (24) as at that date.

Indeed, N406.4 billion was reported as funds raised by banks from the capital market, out of which N306.0 billion was verified and accepted by the CBN. Consequently, the post- consolidated capital base of banks rose to US\$5.9 billion from the previous pre-consolidation level of US $\$ 3.0$ billion.

2.4.1 Post-Consolidated Banking System: Implication on SMEs

This paper examines three periods of SME financing policies by the Monetary Authorities:

- Period of mandatory banks' credit allocations of 20 per cent of total credits to SMEs, 1992 -1996

- Banks' pre-consolidation period, 1997-2005, and

- Banks' post-consolidation period, 2006-2010

\section{(i) Period of Mandatory Banks' Credit Allocations to SMEs (1992-1996):}

The Monetary Authority's policy on indirect financing of small scale enterprises through the use of monetary policy instruments started in 1992. The monetary policy stance of the authorities in 1992 classified small scale enterprises, with agriculture, as the "preferred" sector of the economy. Consequently, a minimum mandatory credit allocation of 20 per cent of total credit to the economy was levied on banks' aggregate lending. During that year, total credit to the economy stood at N41.8 billion. Of this amount, N20.4 billion (48.8 per cent) was loaned to small scale enterprises. The level of compliance, however, declined progressively in subsequent years. For example, whereas total credit to the economy increased to N48.1 billion and N92.6 billion in 1993 and 1994 the share of credit to SMEs declined to 32.2 percent (N15.5 billion) and 22.2 percent (N20.6 billion) respectively. In 1995, aggregate credit to the economy rose further to N141 .1 billion, whereas the share of SMEs rose less than proportionately to N32.4 billion, representing 22.9 per cent of total credit in that year. By 1996 when the announcement abolishing the mandatory banks' credit allocations to SME (including agriculture) was made on October 1, total credit to the economy stood at N169.2 billion out of which N42.3 billion or 25.0 percent was loaned to SMEs.

Table III shows that cumulative loans to the economy during the five-years period, 1992- 1996 amounted to N492.9 billion while cumulative total credit to SMEs stood at N131.1 billion, representing mean ratio of 26.6 per cent for the period.

\section{$<$ Insert Table 3>}

It is instructive to note that the mean ratio of credit granted to SMEs during the period was well above the mandatory 20.0 percent prescribed by the Monetary Authorities for the "preferred sector".

The mandatory banks' credit allocations period was biased towards SME financing and may therefore be considered as not a good platform for comparing the normal market-determined trend in SME financing before and after banks' consolidation. However, the period offers a useful insight into the demand by SMEs and possible ways that could assist the Monetary and Federal Authorities in boosting SME financing through the banking system.

\section{(ii) Banks' Pre-Consolidation Period (1997-2005):}

The Federal Government policy on liberalization under the structural adjustment programme (SAP) intensified in 1996. Consequently, all forms of restrictions and controls were dismantled to pave way for a free market economy. Therefore, all monetary policies that hitherto dished out directives to banks were abolished. The effect of this policy became manifest in banks' lending preferences from 1997. For example, while aggregate credit to the economy in 1977 almost doubled to N240.8 billon, credit to SME declined to N40.8 billion, representing a sharp decrease to 17.0 per cent of the total credit.

\section{$<$ Insert Table 4>}

Total credit to the economy more than tripled to N796.2 billion and N954.6 billion in 2001 and 2002, but the share of SME declined further to 6.6 per cent and 8.6 per cent, respectively. The figures for 2003 and 2004 passed a trillion naira mark and stood at N1.21 trillion and N1.52trillion with SME share of N90.2 billion (7.5 per cent) and N54.98 billion (3.6 percent) respectively.

At the threshold of consolidation in 2005, aggregate credit to the economy peaked for the period at NI .899 trillion. But the share of SME declined further to 2.7 per cent at a stagnant figure of N50.7 billion. 
Cumulative credit to the economy during the nine-years period, 1997- 2005 amounted to N7,754.5 billion, with accumulated loans to SMEs totalling N505.1 billion, representing a mean ratio of 6.5 per cent for the period.

\section{(iii) Banks' Post Consolidation Period (2006-2008):}

According to the CBN recent published data compiled from returns received from the DMBs from 2006 - 2008, aggregate credit to the economy more than doubled during the post-consolidation period. On the contrary, however, credit to SME declined by more than half in value.

\section{$<$ Insert Table 5>}

Total credit to the economy increased from N2.5 trillion in 2006, N4.8trillion in 2007 and N7.7trillion in 2008. Conversely, total credit granted to SME declined sharply from N25.7 billion (1.02 per cent) in 2006, N41.1 billion ( 0.9 per cent) in 2007 and dropped further sharply to N13.4 billion ( 0.2 percent) in 2008.

Consequently, the post-consolidated loans allegedly granted to the economy during the three-year period, 2006-2008, accumulated to N15, 063.6 billion, whereas accumulated total credit granted to SMEs during the post-consolidation period declined to N80.2 billion, representing a mean ratio of 0.53 per cent for the period. This confirms the findings by many experts that the more banks are capitalised, the fewer loans they grant to the small and medium enterprises. This is the rationale behind the call for special programmes to be put in place to assist the small and medium enterprises, undisputedly recognized as the nucleus of industrial revolution, in most economies of the world.

It should be noted the quantum of credit denied SME sector in the post consolidated period, 2006-2008 based on trends in credit granted to the sector in the past two periods between 1992-1996 and 1997-2005. The analysis is not necessarily based on the credit needed by SME sub-sector that was not granted by the post- consolidated banks during the period. No research has been conducted to come out with accurate figure on the amount of credit needed by the sector (Benjamin, 2009).

However, Table VI indicates that the capitalized banks under- disbursed to SME the sum of N25.7billion, instead of N164.1 billion, representing a shortfall of N138.4 billion in 2006. In 2007, only N41 .1 billion was disbursed instead of N312.9 billion, representing a shortfall of N271.8 billion. In 2008, N502.2 billion was due for disbursement to SMEs but only N 13.4 billion was actually disbursed, leaving a credit gap of N488.8 billion. Consequently, the aggregate credit denied to SME sub-sector during the post-consolidation period, 2006- 2008 accumulated to N898.9 billion as at end-December, 2008.

\section{$<$ Insert Table 6>}

\section{Methodology}

The methodology deals with model specification, data requirement and source of data. Empirical implementation of the model makes use of macroeconomic data covering $1992-2010$ to determine the effect of Pre-Post consolidation on SME financing and its accessibility to finance in Nigeria. The model is designed to explain the leading indicators of SMEs' accessibility to fund in Nigeria. The data used in the study are collected from Central Bank of Nigeria statistical bulletin and publications. The statistical technique to be used is regression analysis.

\subsection{Model Specification}

It would be necessary to establish the empirical model to explain economic variables for this study- the accessibility of SMEs to finance in the Pre-Post Bank Consolidation in Nigeria so as to ascertain whether accessibility of finance to SMEs during Post -Consolidation has improved or not. Hence, the model is specified as follows:

$$
\mathrm{SME}_{\mathrm{AF}}=\mathrm{f}\left(\mathrm{M}_{\mathrm{S}}, \mathrm{EAR}, \mathrm{EXR}, \mathrm{INT}, \mathrm{INF}, \mathrm{PIF}, \mathrm{GtP}\right)
$$

where

$\mathrm{SME}_{\mathrm{AF}}=$ Accessibility of Finance to SMEs, this is proxied with Credit due to SMEs as no research has been conducted to ascertain accurate figure on the amount of credit needed by the sub-sector (Benjamin, 2009).

$\mathrm{M}_{\mathrm{S}} \quad=$ Money Supply, this measure the degree of financial deepening. Financial deepening means increase in volume of all monies in circulation and effective financial deepening will increase loanable funds in the economy.

$\mathrm{EAR}=$ Commercial Banks' Equity-Asset Ratio, this explains the capitalization and recapitalization of banks in Nigeria and to ascertain whether capital adequacy has any effect on the lending ability of banks, most especially SMEs financing in Nigeria or not.

$\mathrm{EXR}=$ Exchange Rate, since our economy is an import dependent economy, this is expected to have effect on the importation of materials. 
INT $=$ Interest Rates, this is expected to drive the supply and demand for loanable funds.

$\mathrm{INF}=$ Inflation Rate, this influences the general activities in the economy.

PIF $=$ Poor Infrastructural facilities (this is proxied with energy consumption), this is expected to impact on SME production if there is constant energy supply.

$\mathrm{GtP}=$ Government Policy, this is expected to impact on the activities of SMEs.

Empirically, it is expected that money supply (Ms) will impact on the accessibility of finance to SMEs as the engine of growth. A positive correlation is expected.

Also, the recapitalization exercise is expected to impact on accessibility of finance to SMEs in Nigeria. Thus, a positive relationship is expected.

Similarly, exchange rate has a bi directional impact on SMEs depending on the economic dynamics obtainable with our local economy. Given that Nigeria is predominantly import-dependent and also considering the fact that we import-investment goods to make consumer goods, it is expected that exchange rate volatility could either work in our favour or against us.

Overtime, the epileptic nature of power supply has been a major constraint on output in Nigeria making production cost, especially, that are spent on heating and lighting becomes very high. Going by the empirical realities of Nigerian economy a negative relationship is expected of a priori between output of SMEs and energy consumption (ECN). Also interest rate determines the demand and supply pattern of loanable funds to SMEs. More so, inflation is expected to influence the general activities in the economy.

The inclusion of government policy as independent variable helps to show the impact of government policy on accessibility of SMEs to financial institutions in Nigeria. On a priori basis it is expected that government policy impacts positively on accessibility of finance to SMEs.

Against this background, the model is specified as follows:

$$
\log \mathrm{SME}_{\mathrm{AF}}=\mathrm{a}_{0}+\mathrm{a}_{1} \mathrm{M}+\mathrm{a}_{2} \mathrm{EAR}+\mathrm{a}_{3} \log \mathrm{INT}+\mathrm{a}_{4} \log \mathrm{INF}+\mathrm{a}_{5} \operatorname{Iog} \mathrm{EXR}+\mathrm{a}_{6} \mathrm{PIF}+\mathrm{GtP}+\mathrm{U} .
$$

$a_{1}-a_{6}=$ parameters to be estimated.

$\mathrm{U}=$ Stochastic or Error term.

$\mathrm{a}_{0}=$ intercept.

More so, non-spatiality of time series data has often been regarded as a problem in empirical analysis. Working with non-stationary variables leads to spurious regression results from which further inference is meaningless. The conventional Dickey-Fuller (DF) and Augmented Dickey-Fuller (ADF) tests will be used to test for the stationarity of the series.

It is noteworthy here that these seven (7) variables are by no means the only variables that do influence accessibility of SMEs to financial institutions in an economy but they have chosen and selected via literature used in this study. This study is, therefore, limited to commercial banks due to the fact that only commercial banks survived the consolidation exercise in Nigeria.

The data utilised for this study include credit to SMEs, money supply, commercial banks' equity / asset ratio, interest rates, inflation rates, exchange rates, level of infrastructural facilities (proxy with energy consumption) The required secondary data to be used for the analysis were obtained from CBN Statistical Bulletin, and Annual Reports and Statement of Accounts (Various Years), CBN Economic and Financial Reports while Government Policy is represented as zero (0) for passive period and one (1) for active period of the Mandated Banks' Credit Allocation to "Preferred Sector".

\section{Data Analysis and Result}

In literature, most time series variables are non-stationary and using non-stationary variables in the model might lead to spurious regression (Granger and Newbold, 1977). Time series properties of macroeconomic variable of most economies, particularly those of the developing economies, are not very satisfactory. In most instances, the data series are not stationary. However, since the data for this study are time series in nature, we investigated their time series properties and order of integration for the variables employed in the model by performing stationarity tests.

Our first step is to determine the order of integration of the variables, that is, we test whether they are stationary in the levels or whether they have to be differenced once or more before they become stationary. The stationarity of the 
series is tested using the Augmented Dickey Fuller (ADF) test statistics to investigate the presence of unit root. The relevance of $\mathrm{ADF}$ test is to avoid biasness in our estimates and spurious regression results.

All the variables except money supply (Ms) and interest rates are not stationary at levels but all variables except few are stationary at first or second-order first difference as summarised in Table VII. The results showed that the ADF statistic for majority of the variables exceed their critical levels at $5 \%$ level of significance.

\section{$<$ Insert Table 7>}

The result in Table VIII reveals that only money supply (Ms) was significant in the Pre and Post-Consolidation. Interest rates (INT) and exchange rates (EXR) were significant before consolidation while equity-asset ratio (representing banks' recapitalization, in this instance) is also significant in the Post-Consolidation. The descriptive statistics (Adj. $\mathrm{R}^{2}$, F-statistic and D-Watson statistic) before consolidation are significant as they are within acceptable bounds. This also shows that it is a useful model as specified in that the whole variable except equity-asset ratio (EAR) and inflation in Pre-Consolidation period were significant than in the Post-Consolidation period, although the intercept in the Pre-Consolidation was not significant like that of Post-Consolidation era. Conversely, all the descriptive statistics mentioned above were found to be within acceptable bounds but the Adjusted $\mathrm{R}^{2}$ of $49 \%$ has no good fit.

In line with Apriori economic thinking, money supply (Ms) and interest rates (INT) in Pre-Consolidation were positively significant at $1 \%$ and $5 \%$ respectively while exchange rates (EXR) was negatively significant at $10 \%$ confidence level in influencing accessibility of SMEs to financial institutions before consolidation. While other explanatory variables except capitalization and inflation in the Pre-Consolidation period are better significant in explaining access of finance to SMEs than Post-Consolidation period in Nigeria. As such a $1 \%$ change in money supply (Ms) or other explanatory variables in the Pre-Consolidation will have a more proportionate impact on the level of access to finance by SMEs than in the Post-Consolidation period in Nigeria either positively or negatively.

\section{$<$ Insert Table 8>}

Empirical results from the Table VIII also reveals that five (5) of the variables in the Pre-Consolidation era (Ms, EAR, INF, EXR, PIF) are correctly signed in line with their hypothesised signs while the other two (2) (i.e. INT, GtP) had wrong signs. These reverse signs expectation could be due to the fact that government put a stop to the Mandatory Banks' Credit Allocation to "Preferred Sector"

On the other hand, the empirical results show that though all the seven (7) variables are correctly signed but only equity-asset ratio (EAR) and inflation (INF) were better significant in the Post-Consolidation than in Pre-Consolidation era. The reason for this could be due to inflation-targeting of Nigerian government and the recapitalization exercise. This implies that Nigerian banks are better capitalized and their lending ability has improved but failed to channel available funds to sectors considered by government to be crucial to development. This is in agreement with Peterson and Rajan (1992)'s finding that small enterprises (in Nigeria) are most likely to face credit rationing because most potential lenders have little information on the managerial capabilities or investment opportunities of such firms and are unlikely to be able to screen out poor credit risks, or have control over borrowers' investment. In the same vein, according to the World Bank (2002) survey report, lack of finance was a key problem in the Nigerian manufacturing sub-sector. Most firms that had relations with banks and were able to access external finance found it costly and insufficient, hence most manufacturing firms in Nigeria identified access to finance as one of the three(3) biggest business problems, the other two(2) being uncertainty and poor infrastructure.

\section{Summary and Conclusion}

In this study, we set out to empirically establish the effect of Pre-Post Bank Consolidation on the accessibility of finance to SMEs in Nigeria using statistical experiment with annual time series covering the period between 1992 and 2010. The study examines the stochastic characteristics of each time series by testing their stationarity using Augmented Dickey Fuller (ADF) test and then estimates Ordinary Least Square (OLS) regression via E-View.

From the empirical results, the study found out that all the explanatory variables except government policy were more statistically significant in the Pre-Consolidation period than in the Post-Consolidation era. This confirms that banks' Post-Consolidation experience in Nigeria has proved the world wide held view that the more banks are capitalized, the fewer credit they grant to SMEs (Benjamin, 2009). Consequently, the Pre-Consolidation expectation that recapitalization of banks would improve SME investments in Nigeria was not upheld. Rather than make credits accessible, convenient and affordable the reverse was the case as it became costlier and inconvenient. 
In short, banks' Post-Consolidation exercise has failed to foster a vibrant and competitive SME sector that could enhance job creation, promote economic growth, reduce poverty and create wealth for Nigerians.

However, the contribution of this research is that it is established that SMEs accessed funds in the pre-consolidation than post-consolidation period and it confirmed that bank consolidation in Nigeria had not, in the short run, improved the accessibility of finance to SMEs which is in contrary to the belief that bank consolidation would strengthen the economy through increased loanable funds to the different sectors of the economy in which SMEs is not an isolation.

As a way forward, these constraints must be addressed. First, government should extend credit guarantee scheme for agriculture under the Agricultural Credit Guarantee Scheme (ACGS) to cover SMEs as this will reduce the risks being faced by banks in accessing finance to SMEs and geared them towards improving credit ratio to the sub-sector.

There is need for government to re-introduce the "Mandatory Banks' Credit to Preferred Sectors" of $1992-1996$ that mandated banks to allocate 20 per cent of total credits to the "Preferred Sector" of the economy, most especially SMEs. "The Guided Deregulatory Credit Framework" would enhance accessibility of finance to SMEs as its absence has done more harm to the economy than the benefit of abolishing it.

There is need to evolve other means of financing SMEs. There is need to integrate Microfinance Banks in Nigeria to play their roles efficiently and the regulatory body should, as a matter of urgency, establish the Apex Microfinance Bank as the clearing house for the Microfinance Banks, thereby saving them from the problem they face at present in dealing with the commercial banks in Nigeria.

There is, also, need for government to address the problem of poor infrastructural facilities needed to achieve economic development in Nigeria. The government should decentralize key infrastructural facilities such as power and energy, transportation, water, etc. into regions, not necessarily states, and allow each region to develop means of solving the problems of key infrastructure only to be supervised by the central government as some regions may find thermal or solar apposite for energy generation.

As a fallout of the above, it is suggested that further research be carried out on this area of study by looking at the impact of informal sector on SMEs financing in Nigeria.

\section{References}

Adebiyi, M. A. (2004). Industrial Finance in Nigeria: Performance, Problems and Prospects, in Adejugbe M. O. A. (Ed.), Industrialization, Urbanization and Development in Nigeria 1950-1999. Concept Publications Limited, Lagos, pp406- 428 .

Adelaja M. (2004). How SMEDAN Plans to Lift Small Scale Enterprises, Small Business Journal, Vol. 3 (183).

Anyanwu, C. M. (2001). Financing and Promoting Small-Scale Industries: Concepts, Issues and Prospects, $C B N$ Bullion, Vol. 25 No.3, July-September, pp 12-15.

Babajide A. R. (2007). Funding of SMEs' Landscape - Evidence, Government Policies, Programmes and Institutional Support, Paper Presented at the Workshop on Strategic for Operationalising Small and Medium Industries Equities Investment Scheme (SMIEIS) in Nigeria, Ikeja, 2007, Nigeria.

Bamanga T. (1994). The Problems of Small and Medium scale Industrial Development in Nigeria, Paper Presented at the National Institute for Policy and Strategic Studies, Kuru for Senior Executives Course, No.16, 1994, pp 10-27

Benjamin I. A. (2009). Financing Gap for Small and Medium Enterprises (SMEs) in the Post-Consolidated Banking Sector in Nigeria, CBN Publication, Vol. 47 No.3, July-September, pp. 38-53

Chizea A. (2002). Small and Medium Scale Enterprises: Problems and Strategies, Small Business Journal, Business Day 12 (15).

Eigbe O. E. (1996). Financing Small and Medium Enterprises (SMEs) in Nigeria: Problems and Prospects, $C B N$ Debt Trends, Vol. 2 No. 1, June, pp. 10-27.

Essien, O. E. (2001). The Role of Development Finance Institutions (DFIs) in the Financing of Small-Scale Industries (SSIs), CBN Bullion, Vol. 25 no.3, July-Sept.. pp. 3-6.

Ihyembe R. H. (2000). Financing SMEs: International Perspective, The Nigerian Banker, pp.46.

Jegede C. T. (1990). The Development of Small and Medium Scale Industry in Nigeria, Management in Nigeria, Vol. 26 no. 3, pp. 8-10.

Khandker, S. (2003). Microfinance and Poverty: Evidence Using Panel Data from Bangladesh, World Bank Research Working Paper 2945. 
Nnanna O. J. (2001). Financing Small-Scale Business Under the New CBN Directive and Its Likely Impact on industrial Growth of the Nigerian Economy, CBN Bullion, Vol. 25 No. 3, July-September, pp9-10.

Nnanna O. J. (2003). The Role of CBN in Enterprises Financing, CBN Bullion, Vol. 27 No. 1, Jan-March.

Obitayo, K. M. (2001). Creating an Enabling Environment for Small-Scale Industries, CBN Bullion, Vol. 25 No. 3, pp. 18.

Okigbo, P. N. C. (1981). Nigeria's Financial System: Structure and Growth, Longman Group Limited, Burnt Mill, UK.

Olorunsola, J. A. (2001). Industrial Financing in Nigeria: A Review of Institutional Arrangement, CBN Economic and Financial Review, Vol. 39 No. 1, March, pp. 40-72.

Onwumere, J. U. J. (2000). The Nature and Relevance of SMEs in Economic Development, The Nigerian Banker.

Peterson and Rajah G. (1992). The Benefit of Firm-Creditor Relationships: Evidence from Small Business Data, Working Paper No. 362, University of Chicago.

Udechukwu, F. N. (2000). Revitalisation of SMEs (1), Business Times, $6^{\text {th }}$ March, pp. 36.

World Bank. (2002), Regional Program on Enterprise Development, Discussion Papers.

-----------. Second National Development Plan (1970 - 1974).

-------.-. Third National Development Plan (1970 - 1974).

-. Fourth National Development Plan (1970 - 1974).

--on (1997), Federal Government Report on the Vision 2010 committee, AG Printing and Publishing Co. Ltd., Abuja, pp. 70-72.

- 1997). "Federal Government Report on the Vision 2010 Committee", AG Printing and

Publishing Co. Ltd., Abuja, pp. 220-222.

Table 1. Employment-Based

\begin{tabular}{|l|l|l|l|}
\hline Organisation & Micro-Enterprise & Small-Enterprise & Medium-Enterprise \\
\hline International Finance Corporation & $<10$ & $10-50$ & $50-300$ \\
\hline Central Bank of Nigeria & & $<50$ & $<100$ \\
\hline $\begin{array}{l}\text { National Association of Small Scale } \\
\text { Industry (NASSI) }\end{array}$ & - & $<40$ & - \\
\hline Accenture & - & $<50$ & $<500$ \\
\hline
\end{tabular}

Source: International Finance Corporation (IFC) Publication, 2001

Table 2. Asset and Revenue Based

\begin{tabular}{|l|l|l|}
\hline Organisation & Small-Enterprise & Medium-Enterprise \\
\hline International Finance Corporation & $<\$ 2.5$ million & - \\
\hline Central Bank of Nigeria & $<\$ 1.0$ million & $<\$ 150$ million \\
\hline National Association of Small Scale Industry & $<\$ 40.0$ million & - \\
\hline Federal Ministry of Industry & $<\$ 50.0$ million & $<\$ 200$ million \\
\hline National Economic Reconstruction Fund (NERFUND) & $<\$ 10.0$ million & \\
\hline
\end{tabular}

Source: International Finance Corporation (IFC) Publication, 2001 
Table 3. Showing Total Loan to the Economy \& Loan Granted to SMEs During 20\% Compulsory Sectoral Allocation in Nigeria

\begin{tabular}{|l|l|l|l|}
\hline \multirow{2}{*}{ Year } & Total Loan to Economy(N' m) & \multicolumn{2}{|l|}{ Loan Granted To SME } \\
\cline { 3 - 4 } & & Amount (N'm) \% of Total & \\
\hline 1992 & $41,810.0$ & & \\
\hline 1993 & $48,050.0$ & $20,400.048 .8$ & \\
\hline 1994 & $92,624.0$ & $15,462.932 .2$ & \\
\hline 1995 & $141,146.0$ & $20,552.522 .2$ & \\
\hline 1996 & $169,242.0$ & $32,374.522 .9$ & \\
\hline
\end{tabular}

Table 4. Showing Total Loan to the Economy \& Loan Granted to SMEs before Consolidation

\begin{tabular}{|l|l|l|}
\hline Year & Total Loan to Economy (N'm) & \multicolumn{1}{|c|}{$\begin{array}{c}\text { Loan Granted to SME } \\
\text { Amount (N'm) \% of Total }\end{array}$} \\
\hline 1997 & 240,782 & $40,844.317 .0$ \\
\hline 1998 & $272,895.5$ & $42,260.715 .5$ \\
\hline 1999 & $353,081.1$ & $46,824.013 .3$ \\
\hline 2000 & $508,302.2$ & $44,542.38 .7$ \\
\hline 2001 & $796,164.8$ & $52,428.46 .6$ \\
\hline 2002 & $954,628.8$ & $82,368.48 .6$ \\
\hline 2003 & $1,210,033.1$ & $90,176.57 .5$ \\
\hline 2004 & $1,519,242.7$ & $54,981.23 .6$ \\
\hline 2005 & $1,898,346.4$ & $50,672.62 .7$ \\
\hline
\end{tabular}

Source: CBN Statistical Bulletin, 50 Years Special Edition, 2008

Table 5. Showing Total Loan to the Economy \& Loan Granted to SMEs after Consolidation

\begin{tabular}{|l|l|l|}
\hline Year & Total Loan to Economy (N'm) & $\begin{array}{c}\text { Loan Granted to SME } \\
\text { Amount (N'm) \% of Total }\end{array}$ \\
\hline 2006 & $2,524,297.9$ & $25,713.71 .02$ \\
\hline 2007 & $4,813,488.8$ & $41,100.40 .85$ \\
\hline 2008 & $7,725,818.9$ & $13,383.90 .17$ \\
\hline
\end{tabular}

Source: CBN Statistical Bulletin, 50 Years Special Edition, 2008

Table 6. Showing Credit Due to SMEs, Actual Credit Granted and Credit Shortfall after Consolidation

\begin{tabular}{|l|l|l|l|l|}
\hline Year & Credit to Economy & Credit Due to SME & Actual Credit Granted & Credit Shortfall \\
\hline 2006 & $2,524,297.9$ & $164,079.4$ & $25,713.7$ & $138,365.7$ \\
\hline 2007 & $4,813,488.8$ & $312,876,8$ & $41,100.4$ & $271,776.4$ \\
\hline 2008 & $7,725,818.9$ & $502,178.2$ & $13,383.9$ & $488,794.3$ \\
\hline Total & $15,063,605.6$ & $979,134.4$ & $80,198.0$ & $898,936.4$ \\
\hline
\end{tabular}

Source: CBN Statistical Bulletin, 50 Years Special Edition, 2008 
Table 7. Unit Root Test on Annual Data on Variables with Trend (1992 - 2010)

\begin{tabular}{|l|l|l|l|}
\hline Variable & At Level & $1^{\text {st }}$ Difference & $2^{\text {nd }}$ Difference \\
\hline Log SME $_{\mathrm{AF}}$ & 0.762 & -0.053 & $-7.011^{*}$ \\
\hline Log Ms & $-6.155 *$ & $-3.651 * * *$ & $-5.884 *$ \\
\hline Log EAR & -1.725 & $-4.497 * *$ & $-4.044 * *$ \\
\hline Log INT & $-4.228 * *$ & -1.053 & $-6.765 *$ \\
\hline Log INF & -1.691 & $-3.350 * * *$ & $-3.932 * *$ \\
\hline Log EXR & -1.471 & $-3.641 * * *$ & $-5.736 *$ \\
\hline Log PIF & -1.834 & $-3.634 * * *$ & -2.884 \\
\hline GtP & -1.512 & $-4.334 * *$ & $-13.175 *$ \\
\hline
\end{tabular}

* Significant at I per cent level

** Significant at 5 per cent level

*** Significant at 10 per cent level

Critical value: $\quad 1 \%$ is $-4.886 \quad 5 \%$ is $-3.829 \quad 10 \%$ is -3.363

Table 8. Results of Static Regression of Equation (ii)

Dependent Variable $=\log \left(\mathrm{SME}_{\mathrm{AF}}\right)$ :

Pre- Consolidation: $1992-\mathbf{2 0 0 5}$

Post- Consolidation: 1992 - 2010

\begin{tabular}{|c|c|c|}
\hline Variable & $\begin{array}{c}\text { Pre-Consolidation } \\
\text { Coefficient }\end{array}$ & $\begin{array}{c}\text { Post-Consolidation } \\
\text { Coefficient }\end{array}$ \\
\hline $\log (\mathrm{Ms})$ & $\begin{array}{l}1.116^{*} \\
(3.408)\end{array}$ & $\begin{array}{l}1.202 * * \\
(2.145)\end{array}$ \\
\hline $\log (\mathrm{EAR})$ & $\begin{array}{c}1.544 \\
(1.475)\end{array}$ & $\begin{array}{l}3.289 * \\
(2.693)\end{array}$ \\
\hline $\log (\mathrm{INT})$ & $\begin{array}{l}1.163 * * \\
(2.457)\end{array}$ & $\begin{array}{c}1.211 \\
(1.521)\end{array}$ \\
\hline $\log (\mathrm{INF})$ & $\begin{array}{c}-0.159 \\
(-0.536)\end{array}$ & $\begin{array}{c}-0.585 \\
(-1.391)\end{array}$ \\
\hline $\log (\mathrm{EXR})$ & $\begin{array}{c}-0.585 * * * \\
(-2.013)\end{array}$ & $\begin{array}{c}-0.726 \\
(-1.445)\end{array}$ \\
\hline $\log (\mathrm{PIF})$ & $\begin{array}{c}-0.798 \\
(-1.680)\end{array}$ & $\begin{array}{c}-0.683 \\
(-1.140)\end{array}$ \\
\hline GtP & $\begin{array}{l}-0.520 \\
(-0.802)\end{array}$ & $\begin{array}{l}-0.515 \\
(-0.747)\end{array}$ \\
\hline $\mathrm{C}$ & $\begin{array}{c}2.660 \\
(0.967)\end{array}$ & $\begin{array}{c}6.302 \\
(1.590)\end{array}$ \\
\hline $\begin{array}{l}\text { KEY: } \\
\text { * Sig.@1\% } \\
\text { **Sig@5\% } \\
\text { ***Sig@10\% }\end{array}$ & $\begin{array}{l}\text { Adjusted R-squared: } 0.811 \\
\text { Durbin-Watson Stat: } 2.07 \\
\text { Schwarz Criterion: } 0.461 \\
\text { F-statistic: } 8.967(0.00)\end{array}$ & $\begin{array}{c}\text { Adjusted R-squared: } 0.490 \\
\text { Durbin-Watson Stat: } 2.12 \\
\text { Schwarz Criterion: } 1.645 \\
\text { F-statistic: } 3.057(0.07)\end{array}$ \\
\hline
\end{tabular}

